\title{
A mixed-method study of Iranian EFL teachers' achieving resiliency: implications for teacher development
}

\author{
Elham Entesari ${ }^{1}$, Mohammad Hosssein Yousefi ${ }^{{ }^{*}}$ (D) and Hedayat Eslami ${ }^{2}$
}

\author{
* Correspondence: mhh.yousefi@ \\ gmail.com \\ ${ }^{1}$ Department of English Language, \\ Bonab Branch, Islamic Azad \\ University, Bonab, Iran \\ Full list of author information is \\ available at the end of the article
}

\begin{abstract}
The present study was an endeavor to investigate the differences between novice and experienced teachers' achieving resiliency in an explanatory sequential mixed method study. Forty Iranian (i.e., 20 novice and 20 experienced) teachers, male and female, participated in the present study in quantitative study who were selected through convenience sampling method from several private language institutes in Tabriz with teaching experience between 2 and 15 years. The Connor and Davidson Resilience Scale (CD-RISC), developed by (Depression and Anxiety 18:76-82, 2003) was used to measure the novice and experienced teachers' resiliency. The results obtained through the independent samples t-test revealed that there was a significant difference between novice and experienced teachers' resiliency. That is to say, experienced teachers were more resilient than the novice teachers. The qualitative data were collected through in-depth interviews, focus group interviews and teachers' stories. The qualitative data were analyzed through interpretative content analysis. The analyzed data suggest that experienced teachers have a complicated repertoire of strategies at their disposal to bounce back from adversity of teaching conditions in comparison with those of novice teachers. The results of the present study have some implications for teacher development and teacher education.
\end{abstract}

Keywords: Resilience, Psychological well-being, Experience teacher, Novice teachers, Teacher development

\section{Introduction}

Teacher resilience is one of the recurring themes in teacher education. It has been investigated in relation to teacher effectiveness, teachers' well-being, teachers' agency and teachers' professional identity. Resilience has been defined in a variety of ways. According to Reich, Zautra, and Hall (2010) definitions of resilience have included not just recovery from stress to a previous level of health but of sustained growth as a result of a healthy response to stressful situations. Likewise, resiliency is "defined as a set of behaviors over time that reflect the interactions between individuals and their environments, in particular the opportunities for personal growth that are available and accessible" (Ungar, 2012, p. 14). Resilience also refers to the "ability to adjust to varied

(c) The Author(s). 2020 Open Access This article is licensed under a Creative Commons Attribution 4.0 International License, which permits use, sharing, adaptation, distribution and reproduction in any medium or format, as long as you give appropriate credit to the original author(s) and the source, provide a link to the Creative Commons licence, and indicate if changes were made. The images or other third party material in this article are included in the article's Creative Commons licence, unless indicated otherwise in a credit line to the material. If material is not included in the article's Creative Commons licence and your intended use is not permitted by statutory regulation or exceeds the permitted use, you will need to obtain permission directly from the copyright holder. To view a copy of this licence, visit http://creativecommons.org/licenses/by/4.0/. 
situations and increase one's competence in the face of adverse conditions" (Bobek, 2002, p. 202).

One of the reasons behind research interest towards exploring novice teachers' building resiliency is the concern over their attrition during their first five teaching years. For instance, McIntyre (2003) asserted that new teachers at risk of leaving the profession express strong unhappiness with their teaching assignments, frustration with the politics of their profession, the lack of adequate resources, and inadequate mentoring support.

Undoubtedly, studies aim to explore the strategies and motivations behind constructing resiliency on the part of the teachers are concerned with teachers' psychological well-being and teaching effectiveness. For instance, Mansfield, Ebersöhn, Beltman, and Loots (2018) pointed out that pre-service teachers may develop capacity for resilience through building personal resources (e.g. motivation; social and emotional competence), understanding ways to mobilise contextual resources (e.g. relationships, support networks), and developing a range of adaptive coping strategies (e.g problem solving, time management, maintaining work-life balance) to manage challenges with a view to maximising adaptive, resilient outcomes (e.g. commitment, job satisfaction, wellbeing, engagement).

Nonetheless, some scholars, rightly, argued that resilience is not only important for novice teachers but for all teachers as it can enhance teaching effectiveness, heighten career satisfaction and better prepare teachers to adjust to education's ever-changing conditions (Bobek, 2002; Gu \& Day, 2007).

Additionally, Rostami and Yousefi (2020) rightly emphasizes the adverse conditions of novice English teachers in private language schools in Iranian context and pointed out that novice teachers need to interact more with their colleagues, pose the problems, and ask for the experienced teachers' feedback and assistance. In the same vein, Rostami and Yousefi (2020) asserted that novice teachers in Iranian EFL context need to interact with colleagues and principals and their critical incidents to enact better agency so that they gain higher professionalism and psychological well-being.

It should be mentioned that much research interest has been devoted to investigating building resiliency in general teacher education while focus on EFL teachers' resiliency seems little. Another motivation for the present study is the fact that much recent studies explored teachers' resiliency who teach at public schools and enjoy the support of the governments. The current study contributes to the literature by investigating teachers' fostering resiliency at private language schools in the Iranian context and it is moreover significant in that it has been done in EFL context. The study also strives to explore the characteristics of resilient teachers. Finally, the present mixed method study was motivated to explore the different types of strategies novice vs. experienced teachers employ to achieve resiliency.

\section{Literature review}

Teacher resilience occurs when individuals harness their personal and contextual resources and use strategies to overcome challenges and maintain their well-being (Mannsfield, Beltman, Broadley, \& Weatherby-Fell, 2016). Emphasizing the role of social factors in building resiliency, Bobek (2002) revealed that new teachers enhance their resilience by fostering productive relationships with people who understand the 
trials and tribulations of teaching, which reinforce the value of what teachers do, and who offer insight into various options available for dealing with a variety of teaching situations. Research, so far, indicate that Strategies teachers employ to manage and regulate their emotions can have positive impacts on their own and their students' well-being (Lee et al., 2016), or negative impacts such as increased teacher stress, emotional exhaustion, burnout and attrition (Ghanizadeh \& Royaei, 2015).

One of the main paradigms in studies on resilient teachers is social ecological framework. Gu (2018) identifies three distinctive characteristics of teacher resilience that are congruent with a social ecological perspective. First, teacher resilience is contextspecific influenced by school cultures which may nurture or inhibit teachers' capacity for learning and development. Second, teacher resilience is role specific in that it has a close association to the strength and conviction of teachers' vocational commitment. Third, being resilient extends further than merely "bouncing back" and is "the capacity to maintain equilibrium and a sense of commitment and agency in the everyday worlds in which teachers teach" (Gu \& Day, 2013, p. 26).

The findings of Beutel, Crosswell, and Broadley (2019) revealed that preservice teachers perceived teaching as a 'take home' job with the intense workload demands and stresses of teaching impacting on their personal as well as their professional lives that precipitated a range of resilient responses. The study also indicated that supervising teachers and professional experience contexts appeared to impact significantly on preservice teacher resilience and their successful adaptation to teaching.

A number of studies have focused more on teachers' abilities and characteristics, such as optimism, problem-solving and reflection skills, or attribution and self-efficacy beliefs (Gibbs \& Miller, 2014) several studies have focused more on the work teachers do to positively adapt to adverse situations (Castro, Kelly, \& Shih, 2010; Ma Mansfield, Beltman, \& Price, 2014). Still lots of empirical studies concentrated on the outcomes of achieving resiliency or what we can call a product-oriented view of the notion. Notwithstanding, many studies, (e.g. Richardson, Neiger, Jensen, \& Kumpfer, 1990), including the current one, conceptualize resiliency as a process. Resiliency is not a quality that is innate. Rather, it is a construct that is relative, relational, developmental and dynamic (Rutter, 1990).

To the best of the researchers' knowledge, no study has been conducted to explore the Iranian EFL private school teachers' resiliency. Therefore, this study attempted to examine the Iranian EFL high school teachers' resiliency as well as finding the differences between novice and experienced teachers' resiliency. Having this purpose in mind, the researchers tried to answer the following research questions:

1. Is there any statistically significant difference between Iranian novice and experienced EFL teachers' resiliency?

2. How do Iranian novice and experienced EFL teachers, in private high schools, come to achieve resiliency in teaching?

3. what are the characteristics of resilient EFL teachers in Iranian Context?

\section{Theoretical framework}

The current study conceptualizes resiliency as process-oriented (Richardson et al., 1990), multidimensional and dynamic (Gu \& Day, 2007).The adopted theoretical 
framework for the current study is an approach views resilience as a multidimensional and complex process, "a dynamic within a social system of interrelationships" (Gu \& Day, 2007, p. 1305). (Kumpfer, 1999) prefers to call these relationships including a series of protective factors, or buffers, that minimize the impact of an adverse situation or event.

Protective factors incorporate not only personal factors, but also external support systems, such as friends and community resources. In addition to protective factors, resilience is usually assumed as a process by which individuals negotiate and overcome challenges in the normal process of living (Richardson et al., 1990). In this study, we hold a view that resilience as a process relies on a model of resilience in which individuals employ specific strategies when they experience disruption and anxiety as a result of an adverse situation (Henderson \& Milstein, 1996). Which, in turn, these resilience strategies allow a person to overcome the adversity and gain new insights which minimize the impact of that adversity for future encounters (Castro et al., 2010).

\section{Method}

Design

The design of the present study was explanatory sequential mixed methods. We collected both quantitative and qualitative data to get an accurate and detailed picture of Iranian EFL teachers' resilience. Explanatory sequential mixed methods are designs in which the researchers first conduct quantitative research, analyzes the results and then builds on the results to explain them in more detail with qualitative research (Creswell, 2003; Riazi \& Candlin, 2014). It is considered explanatory because the initial quantitative data results are explained further with the qualitative data (Creswell \& Plano Clark, 2011). It is also considered sequential because the initial quantitative phase is followed by the qualitative phase (Creswell, 2003). Greene, Caracelli, and Graham (1989) list a number of reasons that researchers should consider using mixed methods. The first, triangulation, seems to be the most commonly cited reason that mixed methods are incorporated into research. We deliberately triangulated the data. Triangulation refers to the use of more than one method while studying the same research question in order to "examine the same dimension of a research problem" (Jick, 1979, p. 602). Our main purpose in adopting mixed method design was to triangulate the data.

\section{Participants}

Forty Iranian (i.e., 20 novice and 20 experienced) teachers teaching at private high schools of Tabriz, participated in the present study. The teacher participants were selected through convenience sampling method from several private high schools in Tabriz. The English teachers who teach at private schools in Tabriz were 400. Out of these 400 teachers, 40 teachers were selected based on the criteria of availability and consent. The teachers' age range was between 24 and 55 and the participants were selected with teaching experience between 2 and 30 years from both genders. Twenty two of the participants were male and the remaining was female. All the participants were volunteered for the present study. There were no obligations for participating in the study. The participants were free to withdraw from the study at any stage of the data collection. 
We have used convenient sampling due to practical limitations imposed on the study. In practice, having access to all members of even an experimentally accessible population to obtain a representative sample is often impossible due to time or financial constraints (Fred, 2011). Instead, researchers access participants from those immediately available, but do not do this randomly. They select their conveniently available sample so that it fulfills the purpose of the study (Woodrow, 2014). We have selected sampling on the basis of availability and consent. That is to say, those teachers who were available for inclusion as the participants and those who were volunteered for the participation have been selected as the sample of our study.

Whatever is available for use becomes the experimentally accessible population (Gall, Borg, \& Gall, 1996). It is to this population the findings of a study can be directly generalized, not to the entire target population. Experimentally accessible population for our study was EFL teachers who teach at private language institutions in Tabriz.

Due to the type of the sampling, convenient sampling, and the nature of the study, the current study does not aim to generalize its findings to the whole population of private EFL teachers in Iran. As Fred (2011) pointed out the word population usually means everyone in a country or a city. Our target population experimentally accessible population in this study were the whole EFL Private language institutions in Tabriz. we believe that in so far as qualitative studies are context -sensitive and their findings are not easily generalizable to other contexts and indeed the purpose of conducting in qualitative studies are to get a detailed and rich picture of the phenomenon under question. we also believe that many factors such as cultural, social, educational, family background, L1 linguistic background, and even historical factors can affect teachers' attitudes and achieving resiliency which makes generalization impossible.

In a nutshell, our prime purpose in conducting the present study is to get a detailed and in-depth picture of Iranian EFL teachers' resiliency as the case with qualitative studies. we would not like to generalize the findings of the present study to whole population in Iran. however, the findings can be generalizable to whole population in Tabriz, Iran.

Out of 40 participants in the quantitative study 16 were participated in the qualitative part of the mixed method. The criteria for participating in the in-depth interviews, focus group interviews and teachers' narratives were mainly based on the participants consent and the time available for both the lead researcher and the participants. Out of 16 participants in the qualitative study 7 were experienced teachers and the others were novice teachers. Twenty three of the participant teachers held M.A in TESOL and 17 teachers had B.A either in TESOL.

\section{Instruments}

Initially, to ensure the homogeneity of teacher participants and their language proficiency, a sample of Preliminary English Test (PET) was administered. The reliability of PET was calculated through Cronbach's alpha. It was estimated as 0.87 . The PET test includes 4 parts of reading, writing, listening, and speaking. The total score of the test was out of 70. The allocated time for answering the questions was 2 hours.

Moreover, the Connor and Davidson Resilience Scale (CD-RISC), developed by Connor and Davidson (2003) was used in the present study to measure the novice and 
experienced teachers' resiliency. The questionnaire includes 25 items on a 5-point Likert scale with rating responses varying from 0 (not true at all), 1 (rarely true), 2 (sometimes true), 3 (often true) to 4 (true nearly all the time). The CD-RISC measures level of resilience as well as qualities that help one to cope, adapt, bounce back and even succeed in adversity. These are qualities such as self-efficacy, perseverance, competence, tenacity, feelings of control, perception of meaning, and goal achievement. The total resilience score ranges from 1 to 100, with a higher score demonstrating higher levels of resilience. The internal consistency of the questionnaire was calculated through Cronbach's alpha. It was estimated as 0.92 .

In addition, the content validity of the questionnaire was confirmed by three experienced teachers.

The interview questions were developed through reviewing the literature and a smallscale pilot study was conducted to judge the efficacy of the questions. Finally, in indepth and focus group interviews the following questions were addressed:

1. Describe any social support you receive during hardships of your teaching?

2. Do you utilize any environmental resources to bounce back from adversity?

3. Do you utilize any personal resources to bounce back from adversity?

4. Describe any factors keep you motivated in challenging conditions of your teaching?

5. How do you cope with the stressors in your profession?

\section{Qualitative data collection}

The data for the present study come from a variety of sources: in-depth interviews, focus group interviews, and focus group interviews. Creswell and Creswell (2018) pointed out that focus groups are group interviews (typically involving 5-12 people) that rely on the interaction within the group and the questions asked of the moderator to provide insight into specific topics. The primary advantage for the researcher in conducting focus groups is the ability to observe a large amount of interaction among multiple participants on one or more topics in a limited amount of time (Ronald, Jackson, Drummond, \& Camara, 2007). Another source of the qualitative data collection was teachers' narratives. From the perspective of narrative inquiry, individuals are storytelling organisms and narrative researchers deal with how human beings experience the world and how they make meaning of their experiences (Connelly \& Clandinin, 1990).

\section{Procedures}

First, 40 Iranian (i.e., 20 novice and 20 experienced) teachers teaching at private high schools in Tabriz, Iran participated in the present study. The teacher participants were selected with teaching experience between 2 and 30 years from both genders.

Moreover, the Connor and Davidson Resilience Scale (CD-RISC), developed by Connor and Davidson (2003) was used in the present study to measure the novice and experienced teachers' resiliency. The questionnaire includes 25 items on a 5-point Likert scale with rating responses varying from 0 (not true at all), 1 (rarely true), 2 (sometimes true), 3 (often true) to 4 (true nearly all the time). In addition, the resilience questionnaire was once given to group A (e.g., Novice teachers), and another time, the 
questionnaire was given to group B (e.g., Experienced teachers). Also, it should be mentioned that the teacher participants were called for answering the PET test and questionnaire during their regulate class time and without any limitation. In addition, the reliability of the questionnaires was calculated through Cranach's alpha and it was 0.92. Moreover, their validity was confirmed by three experienced teachers.

Also, it should be mentioned that before conducting the data collection, ethical considerations were adopted in the completion of the research. As well, teacher participants were informed about the objectives of the present study and they were guaranteed that the results would be kept confidential and no other use would be done by their responses.

As highlighted earlier, the qualitative data come from different sources: in-depth interviews, focus group interviews, and teachers' stories. Upon gaining written consent of the participants, the lead author conducted face to face interviews with 16 participants who also participated in quantitative phase of this mixed method study. Each interview session lasted between 30 and $45 \mathrm{~min}$. All the procedure was audio-recorded for the data analysis. The participants were free to have their interviews either in Persian or English. Three out of sixteen participants answered interview questions in English; the remaining had their interviews in Persian. All the data were transcribed by the lead author. She emailed the transcribed data to the second and the third authors. All three researchers independently codified the data. They had a session discussing which quotations ought to be included in the study. The selected quotations were translated by the first and second author independently and they emailed the translated quotations to each participant to verify it. All mismatched were settled through negotiation and communication among the researchers and participants. The lead author also conducted focus group interviews. Focus group interviews had three groups: the first one had six participants and the other two groups had five participants. The lead researcher played the role of the moderator and guided the discussions to shed much light on the issue under question. Each focus group interview lasted between one hour and one hour and a half. The focus group interviews were also audio taped and the first two authors involved in transcribing the data. Finally, the lead author sought participants' stories on resilience.

\section{Results}

To compare the teachers' resiliency between two novice and experienced groups, the researcher administered the Connor and Davidson's (2003) teacher resilience questionnaire to 40 teachers. Table 1 indicates the results of the descriptive statistics of teacher resiliency scores.

As is clear from Table 1, the mean score and standard deviation of the novice teachers' resiliency scores were 52.10, and 5.15, respectively, while the mean score and standard deviation of the experienced teachers' resiliency scores were 55.70 and 5.68. It was revealed that the mean score of the experienced teachers was higher than the mean

Table 1 Descriptive Statistics of the Novice and Experienced Teachers' Resiliency Scores

\begin{tabular}{lllll}
\hline Groups of Teachers & N & Mean & Std. Deviation \\
\hline Teacher Resiliency Scores & Novice Teachers & 20 & 52.10 & 5.15 \\
& Experienced Teachers & 20 & 55.70 & 5.68 \\
\hline
\end{tabular}


score of the novice teachers in teacher resiliency. Before running the Independent samples t-test to compare the significance of the difference between the mean scores of two groups, it was essential to check the normality of the teacher resiliency scores' distribution. For this purpose, the researcher ran the One- sample Kolmogorov-Smirnov test. Table 2 shows the results of the analysis.

As it is illustrated in Table 2, the $p$-value of .086, higher than the alpha level, $.05(p=.086>.05)$ revealed that the teachers' resiliency scores had normal distribution. After the normality assumption was met, Independent samples t-test was run to see whether there was a significant difference between the mean scores of two groups or not. Table 3 displays the results of independent samples t-test.

As Table 3 demonstrates, the p-value in Levene's test for equality of variances was .848. It means that the equal variances were assumed and the results of the first row should be read. Since t $(38)=-2.101, p=.042<.05$, it was revealed that there was a significant difference in the teachers' resilience scores between the novice and experienced teacher groups. Therefore, the first null hypothesis was rejected and the answer to the first research question was affirmative.

The findings achieved from the analysis of the data collected through teacher resilience scores revealed that there was a significant in the teachers' resilience scores between the novice and experienced teacher groups. The results of the present study are in line with the findings of Howard and Johnson (2004), Rutter (1985), in which they indicated that there was a significant difference between novice and experienced teachers' resiliency and contextual factors.

In addition, according to Gu and Day (2007)), p. 1311 the significant difference between novice and experienced teachers' resiliency may be due to the fact that having an inner motivation to teach, "an important professional skill of teachers", was connected with teacher's resilience. As well, as Greenfield (2015) argued, teachers 'associations with others, and actions (problem-solving, etc.) proceed as a defense to protect their thoughts from negative effects. Also, early childhood education teachers feel themselves better, make healthy decisions, and chase a healthy life when matched up to the other groups of the society (Ylitapio-Mäntylä, Uusiautti, \& Määttä, 2012). Being more experienced and having their own classrooms might donate in-service teachers to have higher occupational resilience beliefs. We hypothesize that one justification behind the differences between novice and experienced teachers' resiliency is the fact that from the initial years of teaching, experienced teachers begin to develop a repertoire of skills mainly coping strategies as how to build and foster resiliency in their profession. In

Table 2 One-Sample Kolmogorov Smirnov Test for the Teachers' Resiliency Scores

\begin{tabular}{lll}
\hline & & Resiliency Score \\
\hline Normal Parameters ${ }^{a, b}$ & & 40 \\
& Mean & 53.90 \\
Most Extreme Differences & Std. Deviation & 5.65 \\
& Absolute & .130 \\
& Positive & .130 \\
Test Statistic & Negative & -.063 \\
Asymp. Sig. (2-tailed) & & .130 \\
\hline
\end{tabular}


Table 3 Independent Samples T-test for the Novice and Experienced Teachers' Resiliency Scores

\begin{tabular}{|c|c|c|c|c|c|c|c|c|c|c|}
\hline & & \multicolumn{2}{|c|}{$\begin{array}{l}\text { Levene's } \\
\text { Test for Equality } \\
\text { of Variances }\end{array}$} & \multicolumn{7}{|c|}{ t-test for Equality of Means } \\
\hline & & \multirow[t]{2}{*}{ F } & \multirow[t]{2}{*}{ Sig. } & \multirow[t]{2}{*}{$t$} & \multirow[t]{2}{*}{$d f$} & \multirow[t]{2}{*}{$\begin{array}{l}\text { Sig. } \\
\text { (2-tailed) }\end{array}$} & \multirow[t]{2}{*}{$\begin{array}{l}\text { Mean } \\
\text { Difference }\end{array}$} & \multirow[t]{2}{*}{$\begin{array}{l}\text { Std. Error } \\
\text { Difference }\end{array}$} & \multicolumn{2}{|c|}{$\begin{array}{l}95 \% \text { Confidence } \\
\text { Interval of the } \\
\text { Difference }\end{array}$} \\
\hline & & & & & & & & & Lower & Upper \\
\hline \multirow[t]{2}{*}{$\begin{array}{l}\text { Resiliency } \\
\text { Score }\end{array}$} & $\begin{array}{l}\text { Equal } \\
\text { variances } \\
\text { assumed }\end{array}$ & .037 & .848 & -2.101 & 38 & .042 & -3.60 & 1.71 & -7.07 & -.13 \\
\hline & $\begin{array}{l}\text { Equal } \\
\text { variances } \\
\text { not assumed }\end{array}$ & & & -2.101 & 37.645 & .042 & -3.60 & 1.71 & -7.07 & -.13 \\
\hline
\end{tabular}

contrast, being novice to the profession, beginner teachers are unable to attain such a rich and sophisticated set of skills to construct resiliency.

\section{Results of qualitative study}

\section{Describe any social support you receive during hardships of your teaching?}

Novice and experienced teachers answered differently to this question. As the data analysis revealed they enjoy receiving social support differently in the teaching milieu. Leila, 42, who teaches at a private language institute in Tabriz and has been teaching English for more than 15 years, had the following to say:

I usually receive social support from my colleagues. As far as my teaching milieu is concerned, I believe that we possess some sort of community in which we receive social support from each other and also support our colleagues in return. We have three novice teachers in our language institute. sometimes they have problems with class management and resolving critical incidents, we all support them emotionally and cognitively and give them directions as how to cope with those problems.

It seems that Leila's experience has its roots in the community of practice paradigm. She backs her colleagues in the demanding and challenging times and in return, she receives social support from her experienced co-workers. She doesn't enjoy receiving support from her family or anyone else. She has achieved professional development and even assists her colleagues to foster their resiliency and enhance their psychological well-being. The strategy that Leila employs to achieve resiliency was seeking help. For her, building resiliency for novice teacher can be conceptualized as having cognitive, affective, and instructional facets. In addition, based on her views, it can be conjectured that Leila was optimistic teacher who possess higher level of self-efficacy.

Reza, 25, who is novice teacher at a private language school in Tabriz, pointed out that:

I cannot think of any social support in a real sense. A social support that you can receive in the days of stress and anxiety does not exist at all. If one can assume any social support from their colleagues, it would be more deconstructive rather than constructive. I rarely enjoy any social support from neither my colleagues in the language institute nor from my family members. 
As a novice teacher, Reza complaints about the demanding and challenging side of language teaching in private language institutes in Iran and also dissatisfied with the lack of any social support neither through apprenticeship nor through settling the issue through discussing it with his co-workers. It means that his psychological well-being harms through these demanding conditions. No doubt, his instructional practices in the classroom will be affected by his lower level of psychological well-being and critical incidents will adversely affect his teaching practices. Reza possess lower level of selfefficacy and is unable to exercise agency in his classes.

David, 40, who teaches at a private language institute had his voice:

In case of hardships, the support is generally coming from the private sector rather than public (governmental support). I would like to narrate and share the incidents with my own peers or experienced teachers. I do believe that this type of support would be often more beneficial and constructive. In some cases (e.g. class management), I personally refer to books or social media like Telegram, where colleagues are sharing their concerns.

David's main reliance is on social support that comes from his colleagues. Although, he is an experienced teacher who teachers for more than twelve years, nowadays he feels he is dependent on the assistance and support of his co-workers. This highlights the significance of peer learning in teacher education programs and circles. Another social support for David comes from studying reference books on teacher education and language teaching. This, in turn, stresses the link between teacher development and teachers' psychological well-being. David possesses self-efficacy and self-confidence. He is, moreover, an optimist teacher.

Shiva, 36, who is an experienced teacher elaborates on the issue:

Emotional support, most of the time, is offered by my colleagues and friends. Sometimes, I receive some sort of directions and suggestions from the head of the language institute in which I teach for more than ten years.

Shiva asserted that she receives two types of support in her teaching milieu: emotional support and instructional support. She receives emotional support from her colleagues and friends, whereas, she enjoys receiving instructional support and educational directions from her head of the institute. It should be stressed that both emotional and educational variables might impact teachers' resilience and psychological well-being. In another words, teacher development courses can assist teachers achieve resiliency easily and effectively. Satisfied with her profession, she is optimistic over her teaching.

Saber, 43, who teaches for more than 15 years, in a private language institution answered our interview question in the following fashion:

I try to solve my own problems since I enjoy solving the dilemmas of teaching through research. I sometimes get supports from my own co-workers especially in private language institutes. 
Saber's views reveal that he is interested in conducting action research to achieve resiliency. It is evident that action research can help him to find theoretical answers to his practical and contextual problems and questions. Moreover, he seeks assistance from his colleagues in private language institutions. Establishing interaction and achieving collaboration among teachers in teaching contexts will help language teachers achieve higher degree of psychological well-being. It should be mentioned that conducting action research on the part of the teachers will inevitably affect teacher development and teachers' resilience. Saber possesses a higher level of self-efficacy and self-confidence.

Shapour, 48, who teachers in private language institutions for more than 20 years answered our question in the following way:

I receive social support from different people: from the head of the language institute, from my own students, and finally from their parents. Actually, I have close relationships with my students. It means that I rarely have class management problem. I don't have any critical incidents that adversely affect my teaching in that sense. I think that I have a higher level of psychological well-being. I consider myself as a happy teacher and I personally believe that nothing is contiguous than happiness.

It is well obvious that Shapour is satisfied with his profession because of his psychological well-being. For him, teaching is a pleasant endeavor. He has positive attitude towards his career, his students, the head of the institute, and the parents involved. Perhaps, the close relationships and social support from among these people was a determining positive factor in his job satisfaction and sense of delight. This can be an ideal condition in which teacher educators can aim to achieve. Shapour possesses a high level of self-efficacy, job-satisfaction, and psychological Wellbeing.

\section{Do you utilize any environmental resources to bounce back from adversity?}

Latif, 32, who is a novice teacher, believes that:

Yes, I sometimes use a various place instead of class. Sometimes, I go to institute's yard to take a walk or go to coffee shop to be with my friends and family. Sometimes, I visit our garden and enjoy the peace of my mind in nature.

Latif utilizes different types of coping strategies to achieve resiliency. Being with different people including his family and friends and visiting different places including nature and garden would assist him when he feels frustrated and disappointed. Coping strategies can be incorporated into teacher education courses in an attempt to raise teachers' psychological well-being.

Rostam, 36, is an experienced teacher. He comments on using environmental factors: 
First, receiving feedback from my peers has been effective technique. Secondly, referring to the sourcebooks has always been beneficial to me, because they are based on my own experience.

Rostam amalgams social and personal resources here, he rightly mentioned that he receives feedback from his peers. Indeed, peer learning is a recurring theme in teacher education. He assumes referring to sourcebooks as social resource. It can be considered as teacher development technique that is undoubtedly a personal repertoire rather than social one. In addition to being a practitioner, Rostam theorizes from his practices. He, in a sense, conducts action research.

Samin, 27, a novice teacher had her voice in the following fashion:

I find environment recourses helpful from time to time. Recourses are such as visiting nature, since we cannot ignore its importance in human life and putting ourselves into calmness.

Samin doesn't talk about seeking relief from his peers, family members, friends, and administrators in any real sense. She rather prefers to visit nature and enjoy the peace of mind in the relaxing environment. Psychologically speaking, her resiliency can be achieved in the nature.

\section{Do you utilize any personal resources to bounce back from adversity?}

Leila, 26, a novice teacher had her voice in the following way:

I don't use any personal resources to achieve resiliency. In fact, I don't have much experience. The only thing that I can do is to seek help from experienced teachers. I usually ask help from my co-workers in both private language schools whenever I have a problem that is related to my job.

Leila's viewpoints reveal that her sole reliance is on environmental or social resources rather than personal. The explanation might be the fact that she is a novice teacher. Her professional identity and agency presumably lead her to take such measures in her professional life.

Another novice teacher, Rahman, who teaches English, answered our question in the following manner:

First of all, I trust in God. I believe that he will bless me and my instructional practice in the classroom. Then, I try to make analysis of the adverse situation. Considering any problem, I do believe that any difficulty can be settled through negotiation and compromise.

Rahman's words illustrate that he utilizes a combination of personal and social resources. He mainly relies on his religious beliefs to calm down himself. He utilizes his critical analysis as well as his judgment to analyze the situation. He finally interested in settling the issues and resolving critical incidents and adverse situation through 
interaction with people involved including students, parents, and administrators. Certainly, he will achieve higher level of psychological well-being.

Rad, 38, an experienced teacher replied that:

Yes. Sometimes we have to decide quickly. For example, critical incidents are unpredicted and unwanted. They need the quick judge and performance from the teacher. Regularly applying the resources has been helpful.

It seems that Rad is quick in uptake. He comes to a decision quickly. He rightly believes that teaching is a demanding task that sometimes requires your immediate and offhanded decisions and accurate judgments, especially confronting critical incidents. He further believes in the efficacy of such immediate decisions and judgments on part of the teachers.

Saba, 46, utilizes the personal resources in the following way:

I try my best to find a reasonable way in adverse conditions. I most of the time use my experience and expertise to resolve the dilemmas. Of course, if I cannot find a way, I will ask experts for help. I find it helpful in almost every case.

Saba employs a variety of resources to achieve resiliency. She is self-assured that would find a rational way to resolve demanding situations. She has confidence in her experience as well as her professional expertise. She has an extensive repertoire of techniques as how to deal with the problems. Seeking guidance from experts also is another way to find reasonable answers to the dilemmas in teaching classes.

Describe any factors keep you motivated in challenging conditions of your teaching? Fariba, 47, an experienced teacher pointed out that:

Whenever I notice my students are glad because of learning new materials or they themselves suggest doing extra homework I become motivated to work hard and seriously. Sometimes they prefer to hold their birthday celebration in my class I think it shows their feelings towards me and my classes. They are relaxed in the class.

Fariba's close relationship with her students sustains her highly motivated in her professional endeavors and provides her with higher levels of psychological wellbeing. She has taken her classes both as cognitive and affective endeavor. When she grows in psychological well-being, so do her students. Feeling relaxed and experiencing little or no stress on the part of the students makes both teacher and students grow in well-being. This, in turn, will create ideal condition for language learning.

Rostam, 37, is an experienced teacher. He has the following to say:

Observing the results or positive impact after utilizing the technique is a kind of motivator to follow the same routine. Occasionally, the colleagues, frequently novice 
teachers, consult me to offer them a way contributes to solve their issue. Later they would appreciate the way I have suggested. It is somehow a motivator.

For Rostam, the motivators are mainly cognitive and affective. Appreciating he receives from his colleagues and students, observing the impact of his teaching, providing his co-workers with suggestion and feedback are among motivators that sustain him motivated in the days of adversity These factors contribute to his psychological well-being.

Sahar, 23, a novice teacher had her voice in the following way:

I have a goal in my profession; my goal is to be a successful teacher that can inspire my students. I think it is very important to motivate yourself through having goals and to impact your learners.

Sahar is a goal-oriented teacher in her initial phases of teaching. She has established a specific goal and wants to be an inspiring and motivating teacher. She would like to keep herself motivated and wants to motivate her students to be affective learners. She mainly enjoys affective and emotional variables to be an effective and qualified teacher in years to come. In so doing, she will tolerate the adverse conditions and demanding moments of teaching.

Shiva, 36, is an experienced teacher:

As we know different factors such as achievement, advancement, personal growth, autonomy and responsibility include motivational factors. Unfortunately, in Iranian EFL contexts because of the reduced numbers of students and low payment most of the teachers do not have enough motivation to work and teach. But in order to keep teachers motivated we can praise them or reward them. Also, we can encourage them to look for professional development opportunities and also create them those opportunities.

Shiva believes in three different types of motivators in her professional career: emotional, cognitive and professional development. For her, emotional motivator can come from compliments, while, professional development can originate from achievement, personal growth, and autonomy. For Shiva, opportunities for professional development can be regarded as cognitive motivators. It should be mentioned that she suffers from such demotivates as low payment. This, in turn, will lead to her lower level of psychological well-being. She rightly appreciated the position of English teachers; however, she considers social factors trying to demotivate teachers- as a threat. She, as an experience teacher suggests the ways to motivate and raise the professional identity of teachers.

Nezam, 29, a novice teacher believes that:

Certainly, love is the most important factor; love to teaching and studying. Most of the time, I remind my goals in my professional life. Reminding the goals can be of help to keep ourselves motivated. Sometimes, a short beak can be of help. It renews our energy and motivation. Leaning from other peoples' experiences can be beneficial as well. 
Nezam's higher level of job satisfaction can aid him to keep motivated in teaching profession and endure challenging and demanding conditions of language teaching.

\section{How do you cope with the stressors in your profession?}

Faramarz, 48, an experienced teacher had the following:

I love teaching and this extensive love helps me to overcome all the negative factors in my teaching practices. I consider my students as my own children. Hence, like a father I try to solve their problems.

Higher degree of job satisfaction and love for teaching assist Faramarz cope with different types of stressors in his career. His concern for his own students, close and emotional relationship with the students can be of positive energy for Faramarz to tolerate the demanding conditions of teaching.

Salar, 41, an experienced teacher capitalizes on different kinds of strategies to release his stress:

I would like to drive, to listen to music, to search the web. And I want to get information or find a way through consulting my co-workers. I also benefit consulting my brothers who are also my friends and colleagues.

Salar's comments reveal that his main drives for tolerating adverse conditions of teaching come from different sides: relieving himself through listening to music, consulting his co-workers and family members. He, in fact, utilizes a combination of personal and social resources to cope with stress in her professional life. Furthermore, his close ties with his brothers and colleagues can act as an establishing community of practice.

Rasami, 37, is an experienced teacher. He replied our last interview question in the following way:

I study and prepare myself before going to class. I try to know the learners and their needs more. Each learner or class has its own qualities that need teachers to adapt themselves to the situation of class.

Affecting by the tenets of postmethod pedagogy, Rasami thinks that each learner and each class has its own requirements. He further believes that it is teacher who should adapt to different teaching situations. He tacitly believes that stress mainly comes from inability of teachers to meet learners' specific needs and appreciating teaching condition.

Ahmadi, 34, is another experienced teacher who pointed out that:

In the days of doom and depressing, I try to calm down in any situation that puts me under pressure, like through talking about it with the language learners, and try to find a solution in collaboration with my students .Listening to music or searching the net about the related problems are other things that I try in demanding conditions of my teaching profession. 
Other than seeking his colleagues' viewpoints on the problem, Ahmadi has another constructive and reasonable way to resolve critical incidents in the classroom. He settles the issue under question through negotiation with other stakeholders, students. Employing such strategies will aid teachers in achieving resiliency in the classroom and attaining higher levels of psychological well-being on the part of the teachers.

Khabir, 37, is an experienced teacher who pointed out that:

As a teacher, we know that stress is inevitable. First of all, I try to breathe deeply and then to make a lesson plan and be prepared before going to class. And during teaching time in the classroom, I try to create a safe setting for learners and use positive communication as well as sense of humor.

Khabir takes pre-emptive measures to avoid educational-related critical incidents in the classroom. He implicitly believes that teacher preparation is one way to achieve resiliency prior to putting teachers' well-being and mental health into jeopardy. He also capitalizes on positive psychology and sense of humor to soothe learners' probable stress in the classroom.

Elman, 36, an experienced teacher had the following to say:

In the days of adversity and challenging time of teaching, I would like to simply ignore the demotivating factor as far as I can and also making fun of the problem. Finally, I want to get rid of it through thinking positively. Most of the time, I manage to achieve resiliency in my teaching and personal life.

Elman's trend is mainly cognitive one. He tries to ignore the demotivating factor and through thinking positively and gaining insight through positive psychology tolerate the diverse challenges of teaching profession.

\section{Discussion}

The present study showed that experienced teachers are more resilient compared with their novice peers. The findings of the present study also suggest that novice and experienced teachers have different repertoires to achieve resiliency in their professional life. Novice teachers solely rely on social support from their colleagues, whereas, experienced teachers have a rich and complicated repertoire at their disposal to cope with the numerous challenges of language teaching and achieve resiliency. Iranian experienced teachers capitalize on both social and personal resources achieve resiliency.

The results of the present study are in line with the findings of Howard and Johnson (2004), Rutter (1985), in which they indicated that there was a significant difference between novice and experienced teachers' resiliency and contextual factors. In addition, according to Gu and Day (2007), p. 1311, the significant difference between novice and experienced teachers' resiliency may be due to the fact that having an inner motivation to teach, "an important professional skill of teachers", was connected with teacher's resilience. 
The current study contributes to the existing literature on EFL teacher resiliency in private schools. The study highlights the personality traits and different strategies that resilient teachers employ. The study suggests that resilient teachers are self-confident, optimist and have higher degree of self-efficacy (Khanshan \& Yousefi, 2020) in their teaching. In addition, resilient teachers are able to develop close relationship with their collogues and students. They, also, have higher level of motivation and capitalize on their experience and expertise. The study also indicated that resilient teachers conduct action research in their classes, consult reference books on language teaching, and take pre-emptive measures through preparation for teaching to foster their resiliency through avoiding critical incidents.

The results of the current mixed method study also revealed that novice teachers are dissatisfied with the lack of any social support neither through apprenticeship nor through settling the issue through collaborating with teacher educators. The results of the present study are in line with Rostami and Yousefi (2020) in that he pointed out that novice teachers need to interact more with colleagues, pose the problems, and ask for the experienced teachers' feedback. The results of the present study also sit well with (Rostami \& Yousefi, 2020) in that novice teachers need to interact with colleagues and principals and manage critical incidents to enact better agency so that they gain higher professional identity.

It is well evident that the feedback both novice and experienced teachers receive from their colleagues highlights the significance of peer learning in teacher education programs. Support from co-workers can be of two distinct types: emotional support and instructional support. The results of the study suggest that both types can lead to higher levels of psychological well-being of EFL teachers.

Another source of social support for experienced teachers is through studying reference books on teacher education and language teaching. This, in turn, stresses the link between teacher development and teachers' psychological well-being. The present study suggests that unlike novice teachers, experienced teachers are capable of conducting action research in the classrooms. Conducting action research simultaneously will lead to both teachers' professional development and teachers' resiliency. The study also shows that establishing positive relationships in the teaching milieu among students and teachers can be motivating factor for both teachers and learners. Thus, it is suggested that teachers can gain insights from positive psychology to attain resiliency and psychological well-being. The present study also indicated that resilient teachers have positive professional identity perceptions (Rostami \& Yousefi, 2020), they are able to exercise agency in their classes (Rostami \& Yousefi, 2020).

The results of the present study also indicate that experienced teachers capitalize on both personal and social resources to calm themselves down. By personal resources they mean decision-making, problem solving, and critical analysis of the situation, critical thinking and creativity. Notwithstanding, novice teachers solely rely on the social recourses.

The present mixed method study reveals that there are different types of motivators in Iranian EFL teachers' professional career: emotional, cognitive and professional development. It should be emphasized that the participants consider opportunities for professional development both as motivator factor in language teacher and as a coping strategy that aid teachers to bounce back from adversity of teaching. The results of the 
study also reveal that Iranian teachers settle the issue under question through negotiation with other stakeholders including, students, co-workers and administrators. Furthermore, employing such strategies will aid teachers in achieving resiliency in the classroom and attaining higher levels of psychological well-being on the part of the teachers.

\section{Conclusion and implications}

The present study set out to investigate the differences between Iranian novice and experienced EFL teachers' resiliency. The results indicated that there was a significant difference between novice and experienced teachers' resiliency; in other words, experienced teachers are likely to be more resilient in problems faced situations rather than novice teachers. Teacher resilience is vital in teaching and education and must be promoted between teachers, so it needs to be incorporated in language classrooms. It is acknowledged that teachers' resilience may be fundamental to cope with the developments within western society. Teacher trainers should teach in teacher training programs how to be resilient and flexible in stressful and problem-solving situations and try to solve the problems they face. In the present study, the novice and experienced EFL teachers' resiliency were compared and differentiated with each other. Definitely, eradicating the limitations imposed upon the present study, such as the small sample size or convenient sampling method, more research is needed to examine various factors which might be associated with resiliency, such as autonomy, critical thinking, motivation, and the like which all can have a role in teachers' resilience and their ultimate teaching enrichment.

The present study has a number of implications for language teachers and teacher education. First, coping strategies can be incorporated into teacher education courses in an attempt to foster teachers' psychological well-being. It is, moreover, suggested that courses on psychological well-being, resiliency and critical incidents should be incorporated in teacher education curriculum. Teacher educators also are suggested that raise awareness of teachers as how and why to conduct action research in the classrooms in an attempt to enhance their psychological well-being and professional development. Future studies are suggested to investigate the association among teacher resiliency, teacher agency, and teacher professional identity in greater depth.

Acknowledgements

We would like to appreciate the participants of the study as well as the reviewers of the paper.

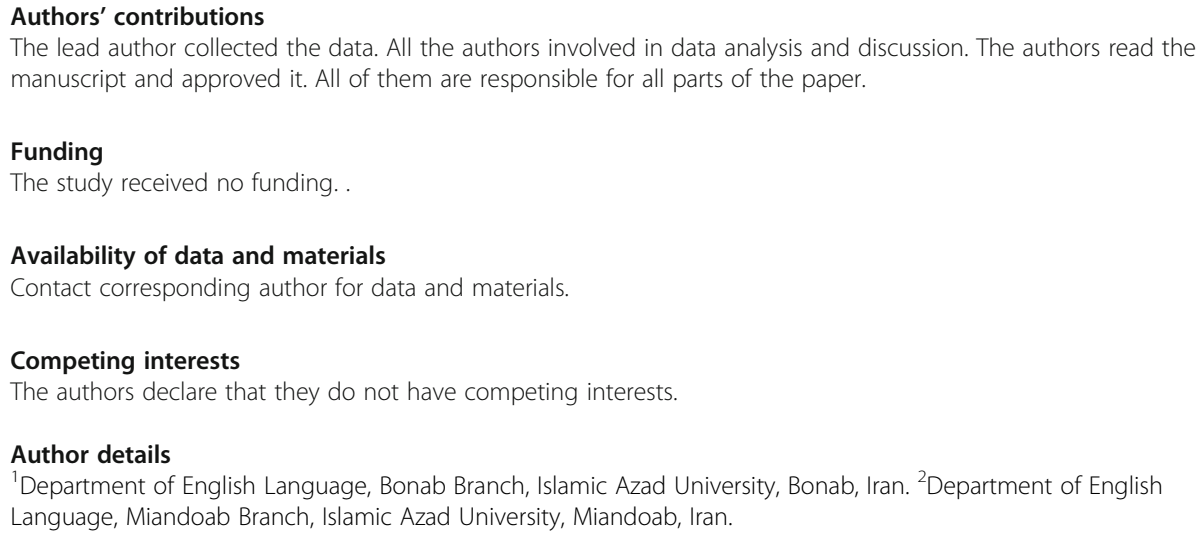


Received: 5 May 2020 Accepted: 6 August 2020

Published online: 28 August 2020

\section{References}

Beutel, D., Crosswell, L., \& Broadley, T. (2019). Teaching as a 'take-home' job: Understanding resilience strategies and resources for career change preservice teachers. Australian Educational Researcher, 46, 607-620. https://doi.org/10.1007/s13384-01900327-1.

Bobek, B. L. (2002). Teacher resiliency. [commentary, qualitative study]. The Clearing House, 75(4), 202-205.

Castro, A. J., Kelly, J., \& Shih, M. (2010). Resilience strategies for new teachers in high-needs areas. Teaching and Teacher Education, 26(3), 622-629. https://doi.org/10.1016/j.tate.2009.09.010.

Connelly, F. M., \& Clandinin, D. J. (1990). Stories of experience and narrative inquiry. Educational Researcher, 19(5), 2-14.

Connor, K. M., \& Davidson, J. R. (2003). Development of a new resilience scale: The Connor- Davidson resilience scale (CDRISc). Depression and Anxiety, 18(2), 76-82.

Creswell, J. W. (2003). Research design: Qualitative, quantitative, and mixed methods approaches, (4th ed). Thousand Oaks: Sage Publications.

Creswell, J. W., \& Plano Clark, V. L. (2011). Designing and conducting mixed methods research, (2nd ed). Thousand Oaks: Sage Publications.

Creswell, W. J., \& Creswell, D. J. (2018). Research designs: Quantitative, qualitative and mixed methods approaches. Fifth Edition. U. S.: Sage Publications.

Fred, L. P. (2011). Research in applied linguistics; becoming a discerning consumer. UK: Routledge.

Gall, M. D., Borg, W. R., \& Gall, J. P. (1996). Educational research: An introduction, (6th ed., ). White Plains: Longman.

Ghanizadeh, A., \& Royaei, N. (2015). Emotional facet of language teaching: Emotion regulation and emotional labor strategies as predictors of teacher burnout. International Journal of Pedagogies \& Learning, 10(2), 139-150. https://doi.org/10.1080/ 22040552.2015 .1113847$.

Gibbs, S., \& Miller, A. (2014). Teachers' resilience and well-being: A role for educational psychology. Teachers and Teaching: Theory and Practice, 20(5), 609-621. https://doi.org/10.1080/13540602.2013.844408.

Greene, J. C., Caracelli, V. J., \& Graham, W. F. (1989). Toward a conceptual framework for mixed- method evaluation designs. Educational Evaluation and Policy Analysis, 11(3), 255-274

Greenfield, B. (2015). How can teacher resilience be protected and promoted? In Educational and child psychology, (pp. 52-68).

Gu, Q. (2018). (re) conceptualizing teacher resilience: A social-ecological approach to understanding teachers' professional worlds. In Resilience in education, (pp. 13-33). Cham: Springer.

Gu, Q., \& Day, C. (2007). Teacher resilience: A necessary condition for effectiveness. Teaching and Teacher Education, 23, $1302-$ 1316.

Gu, Q., \& Day, C. (2013). Challenges to teacher resilience: Conditions count. British Educational Research Journal, 39(1), 22-44.

Henderson, N., \& Milstein, M. M. (1996). Resiliency in schools: Making it happen for students and educators. Thousand Oaks: Corwin Press.

Howard, S., \& Johnson, B. (2004). Resilient teachers: Resisting stress and burnout. Social Psychology of Education, 7, 399-420.

Jick, T. D. (1979). Mixing qualitative and quantitative methods: Triangulation in action. Administrative Science Quarterly, 24(4), 602-611.

Khanshan, S. K., \& Yousefi, M. H. (2020). The relationship between self-efficacy and instructional practice of in-service soft disciplines, hard disciplines and EFL teachers. Asian-Pacific Journal of Second and Foreign Language Education, 5(1), 1-20. https://doi.org/10.1186/s40862-020-0080-8.

Kumpfer, K. L. (1999). Factors and processes contributing to resilience: The resilience framework. In M. D. Glantz, \& J. Johnson (Eds.), Resilience and development: Positive life adaptations, (pp. 179-224). New York: Kluwer Academic/ Plenum Publishers.

Lee, M., Pekrun, R., Taxer, J., Schutz, P., Vogl, E., \& Xie, X. (2016). Teachers' emotions and emotion management: Integrating emotion regulation theory with emotional labor research. Social Psychology of Education: An International Journal, 19(4), 843-863. https://doi.org/10.1007/s11218-016-9359-5.

Ma Mansfield, C., Beltman, S., \& Price, A. (2014). "I'm coming back again!" the resilience process of early career teachers. Teachers and Teaching: Theory and Practice, 20(5), 547-567. https://doi.org/10.1080/13540602.2014.937958.

Mannsfield, C., Beltman, S., Broadley, T., \& Weatherby-Fell, N. (2016). Building resilience in teacher education: An evidenced informed framework. Teaching and Teacher Education, 54, 77-87. https://doi.org/10.1016/.jtate.2015.11.016.

Mansfield, C. F., Ebersöhn, L., Beltman, S., \& Loots, T. (2018). Great southern lands: Making space for teacher resilience in South Africa and Australia. In M. Wosnitza, F. Peixoto, S. Beltman, \& C. Mansfield (Eds.), Resilience in education: Concepts, contexts and connections, (pp. 53-71). Cham: Springer.

McIntyre, F. (2003). Transition to teaching: New teachers of 2001 and 2002. Report of their first two years of teaching in Ontario. Toronto: Ontario College of Teachers Retrieved June 12, 2003, from www.oct.ca.

Reich, J. W., Zautra, A. J., \& Hall, J. S. (Eds.) (2010). Handbook of adult resilience. New York: Guilford Press.

Riazi, A. M., \& Candlin, C. (2014). Mixed-methods research in language teaching and learning: Opportunities, issues and challenges. Language Teaching, 47, 135-173.

Richardson, G. E., Neiger, B. L., Jensen, S., \& Kumpfer, K. L. (1990). The resiliency model [synthesis]. Health Education, 21(6), 33-39.

Ronald, L., Jackson, L. R., Drummond, D. K., \& Camara, S. (2007). What is QualitativeResearch? Qualitative Research Reports in Communication, 8(1), 21-28. https://doi.org/10.1080/17459430701617879.

Rostami, F., \& Yousefi, M. H. (2020). Iranian novice English teachers' agency construction: The complexity dynamic/ system perspective. Asian Journal Second Foreign Language Education, 5, 4. https://doi.org/10.1186/s40862-020$00082-2$.

Rutter, M. (1985). Psychosocial resilience and protective mechanisms. American Journal of Orthopsychiatry, 57(3), 316-331. https://doi.org/10.1111/j.1939-0025.1987.tb03541.x. 
Rutter, M. (1990). Psychosocial resilience and protective mechanisms. In J. Rolf, A. Masten, D. Cicchetti, K. Neuchterlein, \& S. Weintraub (Eds.), Risk and protective factors in the development of psychopathology, (pp. 181-214). New York: Cambridge University Press.

Ungar, M. (Ed.) (2012). The social ecology of resilience: A handbook of theory and practice. New York: Springer.

Woodrow, L. (2014). Writing about quantitative research in applied linguistics Palgrave Macmillian.

Ylitapio-Mäntylä, O., Uusiautti, S., \& Määttä, K. (2012). Critical viewpoint to early childhood education teachers' well-being at work. Journal of Human Sciences, 9(1), 458-483.

\section{Publisher's Note}

Springer Nature remains neutral with regard to jurisdictional claims in published maps and institutional affiliations.

Submit your manuscript to a SpringerOpen ${ }^{\circ}$ journal and benefit from:

- Convenient online submission

- Rigorous peer review

- Open access: articles freely available online

- High visibility within the field

- Retaining the copyright to your article

Submit your next manuscript at $\boldsymbol{\nabla}$ springeropen.com 